Prepared for the U.S. Department of Energy

under Contract DE-AC05-76RL01830

\title{
CHRPR Neutron Board Replacement Manual
}

R Erikson

M Myjak

March 2013

Pacific Northwest

NATIONAL LABORATORY

Proudly Operated by Battelle Since 1965 


\title{
DISCLAIMER
}

This report was prepared as an account of work sponsored by an agency of the United States Government. Neither the United States Government nor any agency thereof, nor Battelle Memorial Institute, nor any of their employees, makes any warranty, express or implied, or assumes any legal liability or responsibility for the accuracy, completeness, or usefulness of any information, apparatus, product, or process disclosed, or represents that its use would not infringe privately owned rights. Reference herein to any specific commercial product, process, or service by trade name, trademark, manufacturer, or otherwise does not necessarily constitute or imply its endorsement, recommendation, or favoring by the United States Government or any agency thereof, or Battelle Memorial Institute. The views and opinions of authors expressed herein do not necessarily state or reflect those of the United States Government or any agency thereof.

\author{
PACIFIC NORTHWEST NATIONAL LABORATORY \\ operated by \\ BATTELLE \\ for the \\ UNITED STATES DEPARTMENT OF ENERGY \\ under Contract DE-AC05-76RL01830
}

Printed in the United States of America
Available to DOE and DOE contractors from the Office of Scientific and Technical Information,
P.O. Box 62, Oak Ridge, TN 37831-0062;
ph: (865) 576-8401
fax: $(865)$ 576-5728
email: reports@adonis.osti.gov

\begin{abstract}
Available to the public from the National Technical Information Service, U.S. Department of Commerce, 5285 Port Royal Rd., Springfield, VA 22161 ph: (800) 553-6847 fax: $(703) 605-6900$ email: orders@ntis.fedworld.gov online ordering: http://www.ntis.gov/ordering.htm
\end{abstract}

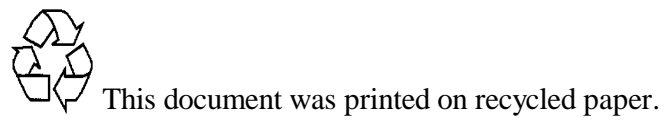




\section{CHRPR Neutron Board Replacement Manual}

R Erikson

M Myjak

March 2013

Prepared for the U.S. Department of Energy

under U.S. Department of Energy Contract DE-AC05-76RL01830

Pacific Northwest National Laboratory

Richland, Washington 99352 
This document describes the process for exchanging the neutron channel boards with gamma channel boards in the CHRPR box. This is necessary to accommodate the desire to have four gamma channels in one box, rather than two gamma channels and two neutron channels, so that one CHRPR box can process data from both the master and slave columns in the TSA system.

After removing the lid from the CHRPR box, the contents should resemble Figure 1.

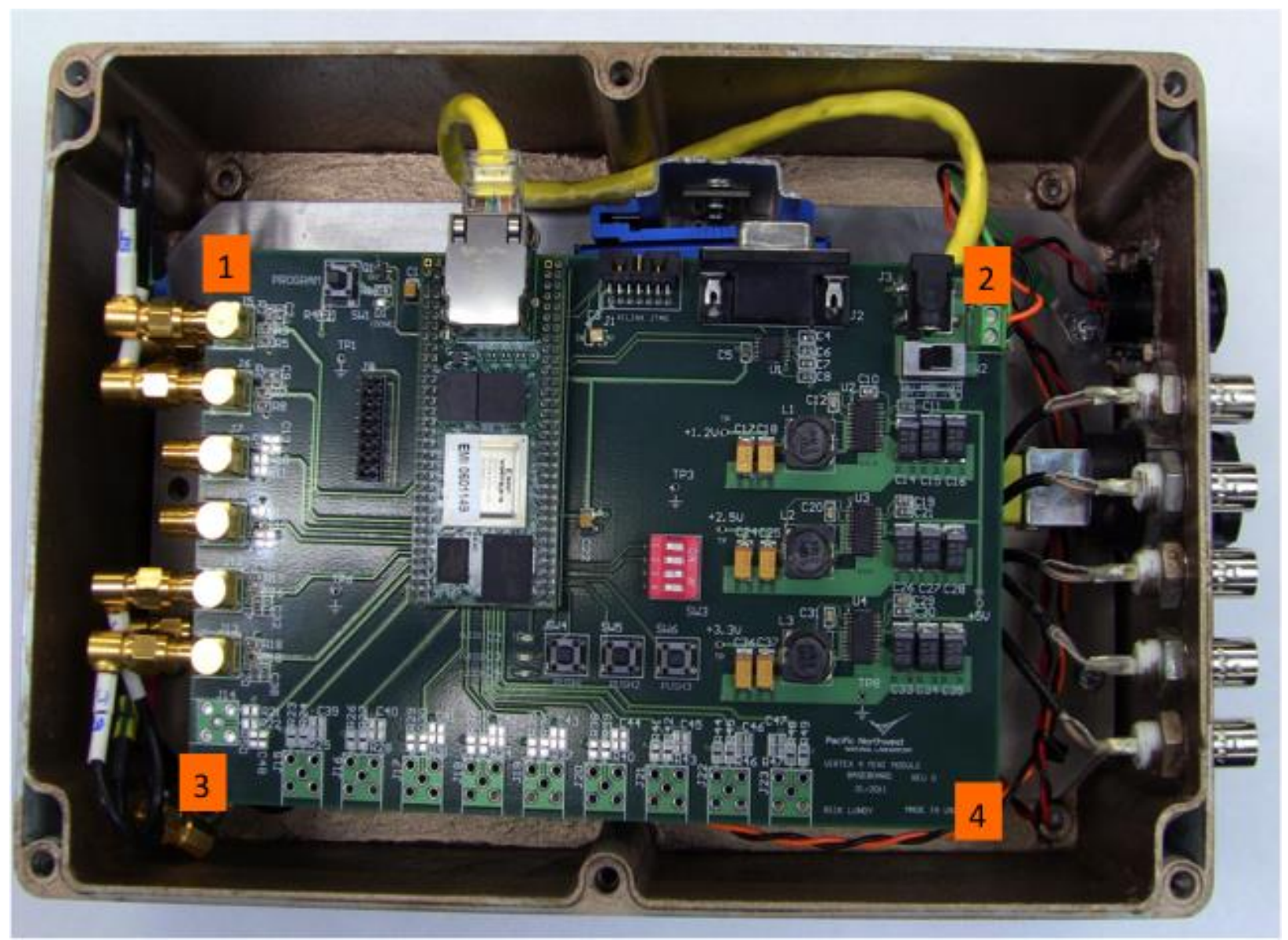

Figure 1. CHRPR Box, Lid Removed

At locations 1, 2, 3 and 4 in Figure 1, remove the screws holding the main circuit board down. Reserve these screws for use when reassembling the box. 


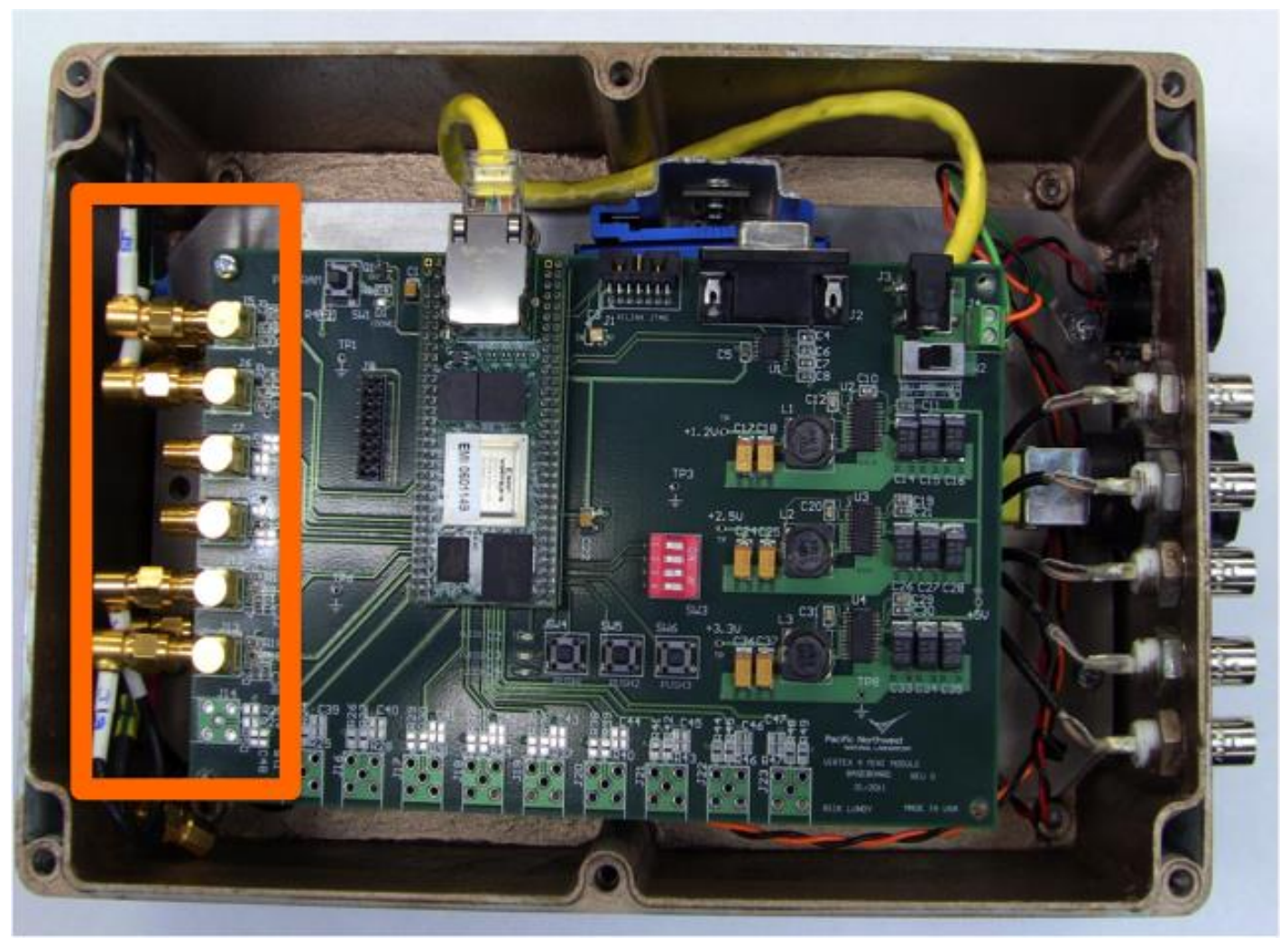

Figure 2. Remove Cable Connectors

Next, remove the cable connectors from the main circuit board by unscrewing each location, boxed in orange in Figure 2 above. Before unscrewing the connectors ensure that the label of each cable matches the circuit board labels as shown in Figure 3. This will ensure accurate assembly when putting the main board back on.

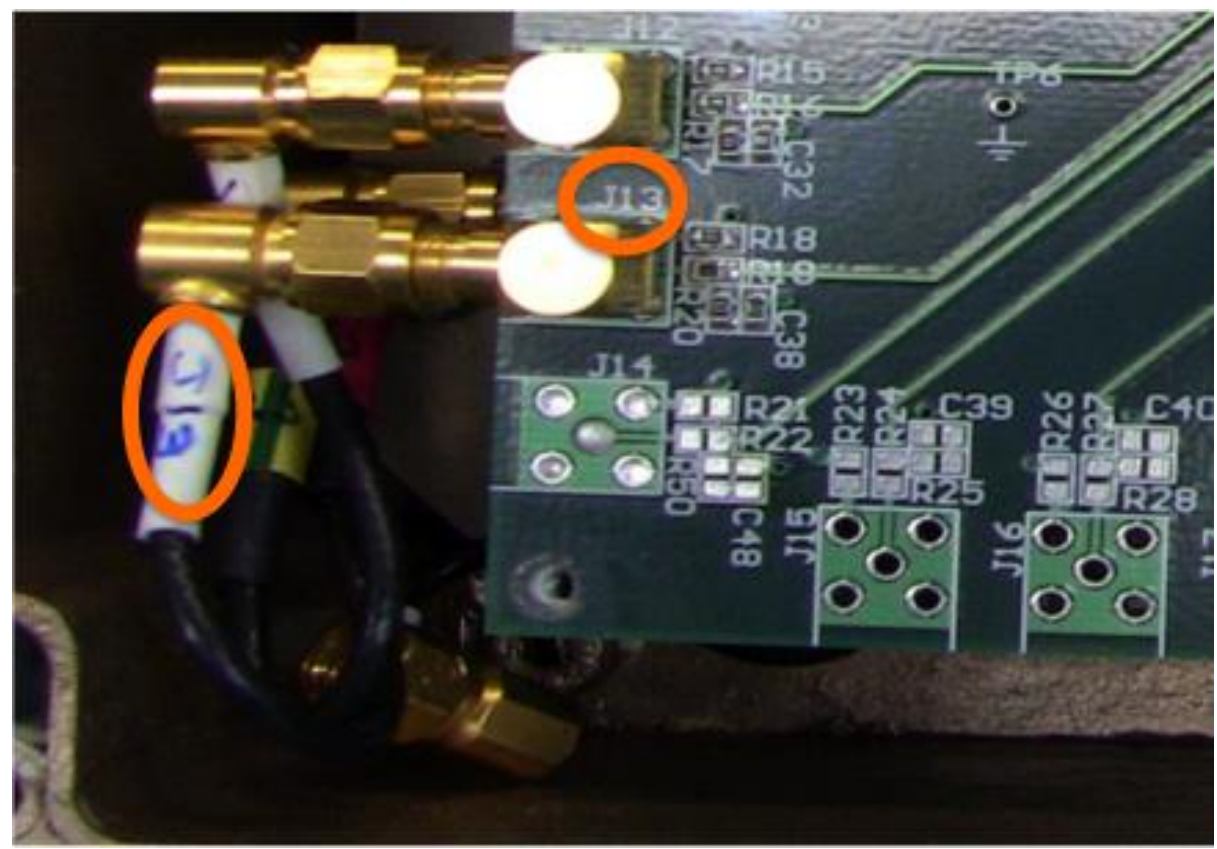

Figure 3. Label on Board and Cable match. "J13" in this case 
Carefully lift the main circuit board up and move it to the side. It is OK if the network cable and other cables are still connected, you should now be able to access the smaller circuit boards below, shown in Figure 4.

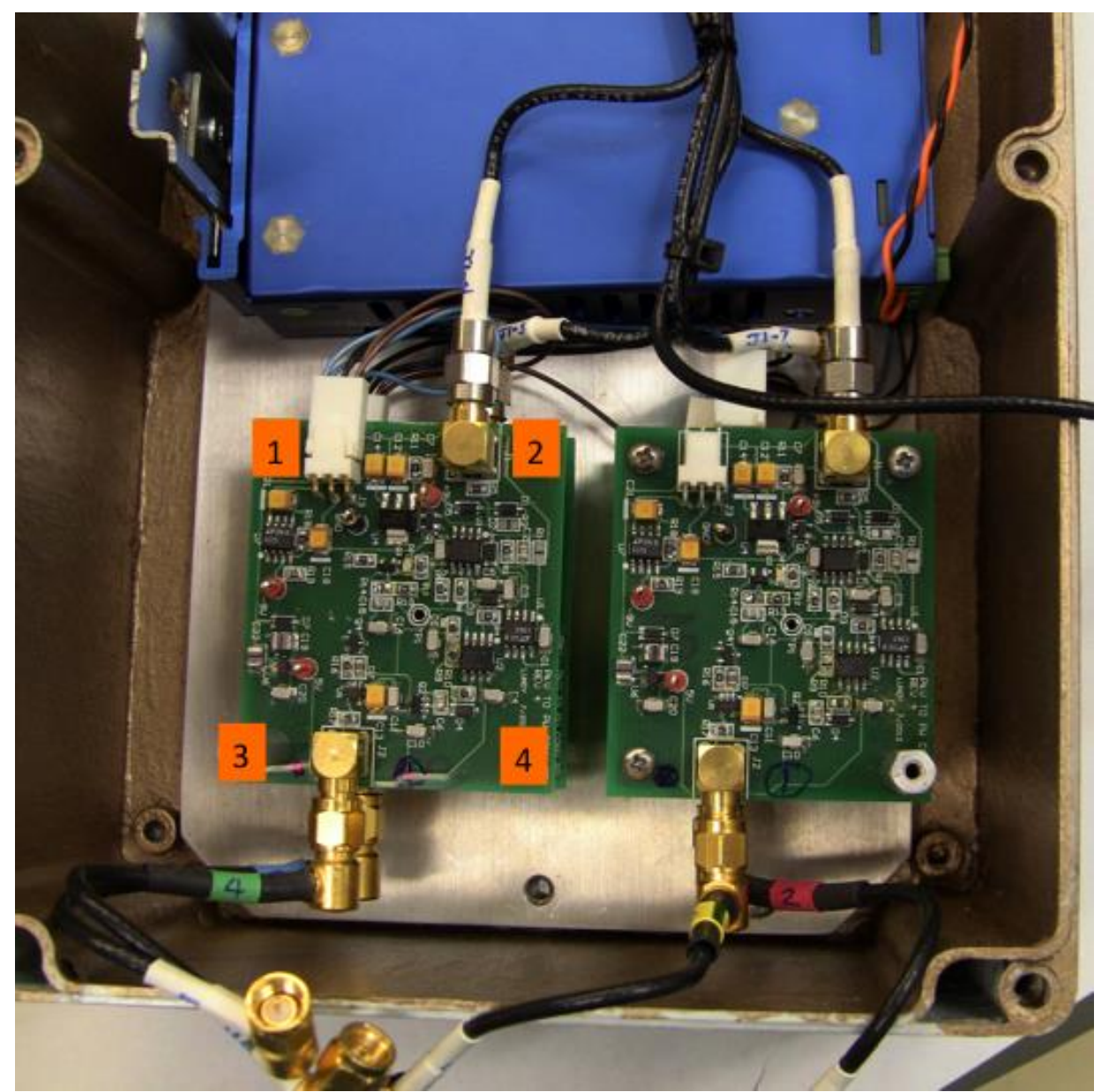

Figure 4. Neutron Board Removal

Now remove the screws at locations 1, 2, 3 and 4 as shown in Figure 4. As was done in Figure 3, ensure each cable connection has a label, or create unique label for each location before the cables are disconnected. Once labels are in place, remove the cables and lift the circuit board from the box. Repeat this step for the circuit board directly below this one.

Replace the boards that were removed with the two new gamma boards, ensuring cables go back to the same locations they were removed from. If the cables are connected to the boards improperly, there is a high risk the boards will be damaged. If the gamma and neutron boards are inadvertently mixed up, observe the number written on resistor R9. The value should be " 470 " for the gamma boards.

Replace the screws removed along the way, and replace the lid. 